annual ice velocities along most of the length of the glacier can be explained primarily by internal deformation without major contribution from sliding at the base. However, the variation of surface velocity with time gives definite indication that sliding occurs in summer and that the average summer rate is increasing progressively from summer to summer and that in a zone 5 to $7 \mathrm{~km}$ below the head of the glacier the summer-to-summer increase in inferred sliding rate is especially rapid. This is a notably distinguishing feature, which is probably indicative of a build-up toward the next surge. In order to obtain direct information about sliding-rates and water pressures at the base in this zone, a bore hole was drilled to the bottom of the glacier about $6 \mathrm{~km}$ below the glacier head. Observations in the hole started in June 1978 and were continued until 31 July 1978 . The hole connected to an englacial water system at a depth of $204 \mathrm{~m}$ whereupon the water level dropped gradually to about $100 \mathrm{~m}$ below the surface. The last $6 \mathrm{~m}$ above the base at $356 \mathrm{~m}$ could be drilled only by means of a cable tool because of the presence of debris-rich ice. Upon reaching the bottom, the water level increased rapidly to the firn water table at about $8 \mathrm{~m}$ below surface. Large variations in water level of about $200 \mathrm{~m}$ occurred during the following period of observation of $35 \mathrm{~d}$. Major events such as audible icequakes, heavy rainfalls, and a period of unusually high ablation were associated with abrupt increases of water level up to the firn water table. High water pressure at the bottom drove a flow of muddy and sandy water upward in the hole. Consequently high freezing rates in the lower $150 \mathrm{~m}$ of the hole produced a very rough bore-hole wall covered with ledges, coral-reef-like features, grooves, and pockets filled with sand. Near the bottom, embedded rocks stuck out of the bore-hole wall. These features were recognized by bore-hole television. The bore-hole bottom consisted of sand which continuously proliferated and washed into the hole. Attempts to remove this sand by means of a sand pump failed, the bailed-out sand being replaced immediately. From bore-hole inclinometry an internal deformation of the ice mass of $0.22 \mathrm{~m} \mathrm{~d}^{-1}$ was obtained. Together with average surface velocity of $0.47 \mathrm{~m} \mathrm{~d}^{-1}$ we get a sliding velocity of $0.25 \mathrm{~m} \mathrm{~d}^{-1}$, averaged over the time of observation. This result confirms the sliding velocities inferred from surface velocity measurements. It also lies on the exponential trend line of increasing summer-to-summer velocities showing a doubling of sliding velocities about every two years (Bindschadler and others, unpublished). This strongly indicates that the next surge is likely to occur in the early eighties. Input of water from the surface probably will play a role in triggering the surge.

\title{
REFERENCES
}

Bindschadler, R. A., and others. 1977. Geometry and dynamics of a surge-type glacier, by R. [A.] Bindschadler, W. D. Harrison, C. F. Raymond, and R. Crosson. Journal of Glaciology, Vol. 18, No. 79, p. 181-94.

Bindschadler, R. A., and others. 1978. Sliding velocity of a surge-type glacier during its quiescent phase of motion, [by] R. [A.] Bindschadler, C. [F.] Raymond, and W. [D.] Harrison. Materialy Glyatsiologicheskikh Issledovaniy. Khronika. Obsuzhdeniya, Vyp. 32, p. 224-29.

Bindschadler, R. A., and others. Unpublished. Variegated Glacier studies 1976, by R. [A.] Bindschadler, W. D. Harrison, and C. F. Raymond. [Unpublished report available from any World Data Center: Glaciology.]

\section{BASAL SLIDING AND BED SEPARATION: IS THERE A GONNECTION?}

\section{By RoBert BINDSGHADLER}

(Geophysics Program, University of Washington, Seattle, Washington 98195, U.S.A.)

Abstract. Analysis of field data from Variegated Glacier supports the conclusion of Meier (1968) that no simple relationship between basal shear stress and sliding velocity can 
be found. On the other hand, an index of bed separation is defined and evaluated that correlates very well with the longitudinal variation of summer sliding velocity inferred for Variegated Glacier. This bed separation parameter is defined as

$$
I \equiv \tau / \mathcal{N}_{\mathrm{eff}}
$$

where $\tau$ is the basal shear stress and is proportional to the drop in normal stress on the downglacier side of bedrock bumps and $\mathcal{N}_{\text {eff }}$ is the effective normal stress equal to the overburden stress minus the subglacial water pressure. The water-pressure distribution is calculated assuming water flow to be confined in subglacial Röthlisberger conduits. The excellent agreement between the longitudinal profiles of $I$ and sliding velocity suggests that calculations of the variation of bed separation can be used to deduce the variation of sliding velocity in both space and time. Further, it is possible that a functional relationship can be developed that adequately represents the geometric controls on basal sliding to permit accurate predictions of sliding velocities.

\title{
REFERENCE
}

Meier, M. F. 1968. Calculations of slip of Nisqually Glacier on its bed: no simple relation of sliding velocity to shear stress. Union de Géodésie et Géophysique Internationale. Association Internationale d'Hydrologie Scientifique. Assemblée générale de Berne, 25 sept.-7 oct. 1967. [Commission de Neiges et Glaces.] Rapports et discussions, p. 49-57. (Publication No. 79 de l'Association Internationale d'Hydrologie Scientifique.)

\section{VARIATIONS IN TIME AND SPACE OF THE VELOCITY OF LOWER GOLUMBIA GLACIER, ALASKA}

\author{
By Mark F. Meier \\ (U.S. Geological Survey, Suite 850, i 20 I Pacific Avenue, Tacoma, Washington 98402, U.S.A.)
}

Abstract. Ice velocity, acceleration, and strain-rate are being measured at intervals of about $45 \mathrm{~d}$ using automated processing of aerial photographs. Preliminary results for the lowest $6 \mathrm{~km}$ of Columbia Glacier for the period July I 976 to November 1977 show the following:

( I) High rates of flow $(2-6 \mathrm{~m} / \mathrm{d}$ ) and longitudinal extension (occasionally exceeding $\mathrm{I} / \mathrm{a}$ ).

(2) A smooth, almost sinusoidal change in velocity $6 \mathrm{~km}$ above the terminus from about $2 \mathrm{~m} / \mathrm{d}$ in August 1976 and 1977 to about $3 \mathrm{~m} / \mathrm{d}$ in February-March 1977.

(3) Very rapid increases in velocity near the terminus in October 1976 and SeptemberOctober 1977 which follow embayment formation (increased iceberg calving).

(4) A suggestion that the rapid velocity increases propagate up-glacier for 3-4 $\mathrm{km}$ before becoming unrecognizable.

(5) Seasonal changes in velocity (which presumably relate to basal sliding) ranging from about $\mathrm{I} \mathrm{m} / \mathrm{d} 6 \mathrm{~km}$ above the terminus to about $4 \mathrm{~m} / \mathrm{d}$ near the terminus.

The rapid increase of velocity near the terminus appears to be caused by the transient increase in effective ice slope due to ice-cliff retreat. The high rate of basal sliding and the velocity peak in mid-winter imply unusual conditions at the bed. If one assumes that the basal water is in the form of a layer punctured by roughness elements (Weertman-Robin), calculation suggests a reversed generalized pressure gradient in this reach, resulting in water storage (unfortunately one cannot be sure of this because the basal shear-stress gradient is difficult to compute near the terminus). If one assumes that the basal water pressure is determined by a Röthlisberger conduit, the pressure in the conduit approaches, or perhaps even exceeds, the basal ice pressure. Thus an unusually thick water layer appears likely, but the seasonal variation remains to be explained. 